\title{
How Delivery of Goods without Tendering of Bill of Lading Can Discharge Liability of Maritime Carrier
}

\author{
Derar Al-Daboubi
}

This paper tends to clarify implications of delivery of goods performed by a maritime carrier to a consignee at the place of destination; particularly, a delivery made without receiving the original bill of lading in exchange for the goods delivered to the consignee. In spite of the importance of such delivery, none of the related international conventions has addressed the implications of such a delivery for the liability of the maritime carrier. This gap has given rise to inconsistency between the approaches adopted by various jurisdictions worldwide, and such a divergence will contradict the fundamental international principle of unifying the international maritime rules. Hence, the study is discussing the area of ambiguity under both the English and the Qatari law to reach some suggestions that could be adopted under both jurisdictions to clarify the legal position of maritime carriers as well as to protect them from liability arising under this delivery.

\section{KEY WORDS}

$\sim$ Bill of lading

$\sim$ Liability of maritime carrier

$\sim$ Qatari law

$\sim$ UK law

$\sim$ Delivery of goods

\begin{abstract}
Al-Ahliyya Amman University, Amman, Jordan
\end{abstract}
e-mail: deraraldaboubi@yahoo.com

doi: 10.7225/toms.v10.n01.021

This work is licensed under (cc) BY

Received on: Oct 15, 2020 / Revised on: Jan 8, 2021 / Accepted on: Jan 14, 2021 / Published: Apr 20, 2021

\section{INTRODUCTION}

Delivery of goods is one of the key obligations imposed upon a maritime carrier under the contract of marine carriage. Significance of this obligation lies not only in its influence on the liability of the maritime carrier, but it is also deemed to be an influential requirement for the commitments of the contracting parties to international sale, under which a contract of marine carriage could be concluded. One area of the effect of delivery of goods can be observed in the context of the liability of the maritime carrier, who would be liable vis-à-vis the shipper or the consignee if the delivery of goods has not been duly performed. ${ }^{1}$ Furthermore, another aspect of significance of delivery of goods is noted in the decisive function of this obligation in deciding the period of the contract of marine carriage. ${ }^{2}$ The aforementioned implications arising from the maritime carrier's performance in handing the goods over to the consignee in the agreed destination have resulted in several conflicting cases brought before courts worldwide. However, the controversy of these disputes becomes more complicated when the delivery of goods has been performed without tendering the bill of lading to the consignee. The complexity can mainly be solved by answering the question of whether or not the obligation of goods delivery is discharged when the delivery had been made without tendering of bill of lading, a question that is not easy to answer due to the vagueness of the rules of goods delivery performed without surrendering of such a document. This dilemma has not been

1. See, A. E Reed \& Co v. Page, Son \& East Ltd. [1927] 1K. B. 743. Todd, P. Principles of the Carriage of Goods by Sea 355 (1 $1^{\text {st }}$ Ed. 2015); Chan Leng Sun, Holder of a Bill of Lading, 7 S.A.c.L.J 355, 362 (1995).

2. Lachmi Singh, The Law of Carriage of Goods by Sea 45, $46\left(1^{\text {st }} \mathrm{Ed} .2011\right)$. 
encountered only under national legislations, but also under the relevant international conventions. ${ }^{3}$

It is admitted that due to the development in the industry of maritime carriage, the goods can in many cases arrive to the destination before receiving a bill of lading by the consignee. ${ }^{4}$ This reality has influenced the practices of the maritime carriage industry, where the maritime carriers found themselves forced to hand the goods over to the consignee regardless of nontendering of the original bill of lading.These circumstances should be taken into consideration because of the practical results reflected from delivering of goods without tendering of bill of lading. ${ }^{5}$ Namely, international and national legal instruments should regulate the delivery of goods without production of this document. This regulation is necessary to define the period during which the maritime carrier shall be responsible for the goods and the implications of this delivery for the obligation of delivery imposed upon the maritime carrier by virtue of the carriage contract as well as the legal impact of such delivery on the rights of the contracting parties to international sales in which the contract of carriage may be included. Therefore, this paper sheds light on the perspective of both the English and the Qatari law, whereby the author has found areas of vagueness in each law and then propose a potential approach that could be followed in order to eliminate ambiguity regarding the rules of handing the goods over without producing the bill of lading. These suggestions aim at balancing the rights of the contracting parties to the marine carriage contract as well as the rights of the contracting parties to international sale.

\section{COMMITMENT OF DELIVERY OF GOODS}

\subsection{Obligation of Delivery of Goods Under Contract of Marine Carriage}

Delivery of goods is one of the commitments imposed upon the maritime carrier under the contact of marine carriage entered into with the shipper. The rule of delivery of goods, enshrined in both international and national instruments, provides that the maritime carrier is only obliged to hand the goods over to the holder of the bill of lading in order to protect the rights of both the shipowner and the legal holder of the bill of lading. ${ }^{6}$ However,

3. See the relevant provisions of Hague/Hague-Visby Rules, Hamburg Rules and Rotterdam Rules.

4. Liu Cheung, Delivery of Cargo Without Production of Original Bill of Lading, 25 JIML 434, 435(2019); Muna Al-Marzooqi, The Documentary Scope of the Carriage of Goods by Sea Articles Under the Qatari Maritime Law and International conventions, 2 International Review of Law 164 (2018).

5. Lixin Han, A Study on the Liability of the Carrier and the Actual Carrier for Delivery of Goods without a B/L in China, 39 J Mar L \& Com 287 (2008).

6. SA Sucre Export v Northern Rovers Shipping Ltd (The Sormovskiy 3068) [1994] 2 Lloyd's Rep 266, 274. these legal sets have adopted different norms for determining the discharge of the obligation of goods delivery that has to be performed by the maritime carrier at the port of destination. According to Hague/Hague-Visby Rules, the obligation of delivery of goods shall be discharged when the goods are taken by the tackle of the ship in the port of destination. ${ }^{7}$ The delivery under Hamburg Rules shall be discharged when the maritime carrier relinquishes the custody of goods to the party entitled to take the goods over at the port of destination. ${ }^{8}$ Although the Rotterdam Rules prolong the duration of liability of the maritime carrier, these rules have followed the same norm of delivery of goods prescribed under the Hamburg Rules. ${ }^{9}$ The Rotterdam Rules stipulate that the maritime carrier shall not be discharged of the obligation of delivery unless the custody of goods is renounced at the port of destination. It is worth noting that English Carriage of Goods by Sea Act (COGSA) 1992 and Qatari Maritime Law (QML) adopt a similar approach to that considered under the Hague/Hague Visby Rules. This rule can be inferred from the provisions of Article 164 of the QML: ${ }^{10}$

[t]he provisions that govern liability mentioned in this chapter shall be applied to maritime transport according to the bill of lading within the period of the loading and unloading the goods on board the Vessel. ${ }^{11}$

Despite that COGSA 1992 did not expressly state this rule, but it is inferred from the related rules of COGSA 1992 that have not expressly regulated the rule of delivery, as this Act provides an access to the provisions of the Hague Visby Rules, that should supersede the provisions of the COGSA 1992 in case the latter contradict the earlier. ${ }^{12}$

Both jurisdictions also prescribed that the maritime carrier is discharged of the obligation of delivery of goods when the holder of original bill of lading tenders this bill to the maritime carrier in return for the goods that have been handed over to

7. Article I(e) of Hague/Hague-Visby rules states: 'Carriage of goods covers the period from the time when the goods are loaded on to the time they are discharged from the ship. See Leung William, Misdelivery of Cargo without Production of Original Bill of Lading: Applicability of the Mandatory Legal Regime of the Hague-Visby and the One Year Time Bar, 39(2) Journal of Maritime Law and Commerce 214 (2008).

8. Article 4(1) of the Hamburg Rules provides: 'The responsibility of the carrier for goods under this Convention covers the period during which the carrier is in charge of the goods at the port of loading, during the carriage and at the port of discharge'. See Simon Baughen, Shipping Law 135, 136 (6 $6^{\text {th }}$ Ed., 2018); Brian Harris, Ridley's

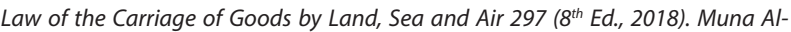
Marzouqi, Carrier Liability Regime under the Qatari Maritime Law: A Comparative Study, 48 J. Mar. L. \& Com. 487 (2017).

9. Article 12(1) of the Rotterdam Rules provides: 'The period of responsibility of the carrier for the goods under this Convention begins when the carrier or a performing party receives the goods for carriage and ends when the goods are delivered. SINGH, supra note 2, at 45, 46.

10. Al-Marzooqi, supra note 8, at. 476.

11. Id. at. 476 .

12. See section 5(5) of COGSA 1992. 
them. This requirement has been adopted by the English court in SA Sucre Export v Northern Rovers Shipping Ltd..$^{13}$ Also, QML has expressly stipulated such delivery. ${ }^{14}$ According to article 153 of QML:

[t]he master shall deliver the goods to the legal holder of the bill of lading. If several individuals holding negotiable copies of a bill of lading have sought a delivery of goods, the holder of the first copy that was endorsed prior to the endorsement of other copies shall be preferred. However, if the goods are delivered in good faith to a holder of one of the copies of the negotiable bill of lading, they shall be preferred over the holders of other endorsed copies even if their endorsements were made prior in time. ${ }^{15}$

From this analysis, it can be concluded that both jurisdictions have not addressed the case where the goods are delivered to the consignee who did not produce the bill of lading. However, the new practices of the carriage of goods by sea, owing to the developments in this industry, have recognised the goods delivery to the consignee who has not received the bill of lading yet. Therefore, these circumstances have to be addressed under both laws to find a legal ground on which the maritime carriers can stand in order to exempt themselves from the liability arising from the delivery of goods without tendering the bill of lading. Therefore, it has been suggested that the maritime carrier may invoke the Letter of Guarantee issued by the consignee in order to be exonerated from the liability of such delivery since this document can entitle them to act as an agent of the shipper in handing the goods over to the consignee regardless of nonsurrendering the bill of lading. ${ }^{16}$ Accordingly, English courts have recognised the goods delivery made by the maritime carrier in the destination port in exchange for the Letter of Guarantee. ${ }^{17}$ This way of delivery has been legalised to protect the maritime carrier from the liability of delivery without production of the bill of lading when the vessel arrived prior to the arrival of the bill of lading. Neither the relevant international conventions nor the QML have regulated such a kind of delivery. ${ }^{18}$ Nonetheless, some conventions have recognised the delivery of goods performed without receiving a bill of lading, but this recognition has been

13. The 'Sormovskiy 3068', supra note 6. at 266, 274.

14. Al-Marzooqi, supra note 8 , at. 466.

15. Id. at. 466

16. Cheung, supra note 4, at 436. The Letter of Guarantee is a document issued by consignee to a shipper for the purpose of legalising the delivery of goods without production of the bill of lading. Laemthong International Lines Co Ltd v Abdullah Mohammed Fahem \& Co [2005] EWCA Civ 519, [2005] 2 All ER (Comm) 167. See $R$ Williams, Letters of Indemnity, 15(5) JIML 394 (2009).

17. Enichem Anic S.p.A. and Others v Ampelos Shipping Co. Ltd (The 'Delfini') [1990] 1 Lloyds Rep. 252; Kuwait Petroleum Corp v I \& D Oil Carriers (The 'Houda') [1994] 2 Lloyd's Rep. 541.

18. Hague/Hague-Visby, Hamburg and Rotterdam Rules all do not regulate the delivery of goods without production of bill lading. confined merely to the delivery that is made to a third party, such as customs or port authority at the port of destination..$^{19}$ It is interesting to say that the English law provides that if the law or customs in the port of destination allows in the strict sense the delivery without surrendering of the bill of lading, the liability of the maritime carrier for the delivery will be discharged. ${ }^{20}$ Contrary to the English law, QML did not regulate the delivery made to the third party at the port of destination as that made to the customs or port authorities. Hence, it can be inferred that the necessity of regulating this delivery lies in the fact of protecting the maritime carrier, who in various scenarios might be obliged to perform the delivery without surrendering the transport documents to complete a series of carriages imposed on them by virtue of various carriage contracts that all entail that the maritime carrier shall call into different ports at the agreed time provided in each relevant contract, and this will enable them to evade potential liabilities that might be borne vis-à-vis the other shippers or consignees.

\subsection{Obligation of Delivery Under International Sale}

The concept of the commitment of goods delivery prescribed in a contract of international sale is not the same as that under the contract of marine carriage, as provided in the rules of the delivery of goods under both international and national legal instruments. However, to illustrate the effect of non-production of the bill of lading on the liability of maritime carrier against the contracting parties to contract of international sale, the analysis will be confined to the concept of delivery of goods imposed upon the seller by virtue of the contract of destination sale, in which a passage of risk shall be determined on the basis of delivery of goods that should be made in the agreed destination. The delivery-of-goods-in-destination sale is addressed under Article 31(b) of the United Nations Convention for the International Sale of Goods (CISG) 1980, by virtue of which

19. Al-Marzooqi, supra note 5, at. 287. It is noteworthy that the Hague/Hague-Visby Rules did not address this kind of delivery, whereas an aspect of this delivery has been regulated under both Hamburg and Rotterdam Rules, where both have allowed such delivery if it has been made to the authority of the destination port in accordance with the law and regulation of the state in which the port is located. According to Article 4(2) of the Hamburg Rules: '[f]or the purpose of para 1 of this Article, the carrier is deemed to be in charge of the goods:... (b) until the time he has delivered the goods:... (iii) by handing over the goods to an authority or other third party to whom, pursuant to law or regulation applicable at the port of discharge, the goods must be handed over. According to Article 12(2)(a) of the Rotterdam Rules: 'If the law or regulation of the place of receipt require the goods to be handed over to an authority or other third party from which the carrier may collect them, the period of responsibility of the carrier begins when the carrier collects the goods from the authority or other third party'.

20. Cooke, J., et al., Voyage Charters, 213 (3rd Ed., 2007). See also, SA Sucre Export v Northern Rovers Shipping Ltd [1994] 2 Lloyd's Rep 275. 
the seller shall be discharged of the delivery obligation once the maritime carrier renders the goods available at the disposal of the purchaser at the destination place..$^{21}$

The norm of the obligation of delivery of goods has further been provided in another international instrument issued by the International Chamber of Commerce (ICC). This is enshrined in Incoterms Rules 2020 that are deemed to be voluntarily applicable rules on contract of international sale of goods. ${ }^{22}$ According to article A2 of DAP Sale (Delivered at Place):

"The seller must deliver the goods by placing them at the disposal of the buyer on the arriving means of transport ready for unloading at the agreed point, if any, at the named place of destination or by procuring the goods so delivered. In either case, the seller must deliver the goods on the agreed date or within the agreed period".

It can be inferred from this article that the seller is discharged of the commitment of delivery imposed in the contract of sale if the maritime carrier placed the goods at the disposal of the purchaser on board the vessel ready for unloading at the agreed place of destination or by entitling the purchaser to procure them so delivered.

The Incoterms Rules 2020 have also provided a different principle of delivery under another kind of destination sale. This has been showed in Article A2 of DPU (Delivered at Place Unloaded):

"The seller must unload the goods from the arriving means of transport and must then deliver them by placing them at the disposal of the buyer at the agreed point, if any, at the named place of destination or by procuring the goods so delivered. In either case, the seller must deliver the goods on the agreed date or within the agreed period".

It can be noted from this Article that the main difference between the delivery norm under DAP and DPU sale is that the delivery under DAP does not require unloading of goods, whereas the delivery would not be discharged under DPU unless the goods have already been unloaded and placed at the disposal of the buyer at the agreed place of destination or by entitling the purchaser to procure them so delivered..$^{23}$

21. As stated in Article 31 of the CISG. See Burghard Piltz, 'Delivery of the Goods and Handing Over of Documents' in Kroll, S. et al., UN Convetion on Contracts for the International Sale of Goods (CISG): Commentary, 412 (Beck/Hart/Nomos 2011); Derar Al-Daboubi, 'To What Extent does the Marine Carrier Influence the Passing of Ownership and Risk in International Sales? A Critical Analysis of the International Instruments and Jordanian Law' 36 (PhD Thesis, Royal Holloway, University of London) (2019); Johan Erauw, 'Passing of Risk' in Kroll, S. et al., UN Convetion on Contracts for the International Sale of Goods (CISG): Commentary 64, 67 (Beck) Hart/Nomos 2011).

22. Juana Coetzee, The Interplay between Incoterms and the CISG, $32 \mathrm{JL} \& \mathrm{Com}$ 6, 7 (2013-2014).

23. Incoterms 2020 Released by ICC. National Association of Credit Management. https://go.gale.com/ps/i.do?p=ITOF\&u=anglia itw\&id=GALE\%7CA611654073\&v $=2.1 \& i t=r$ Accessed 28/09/2020.
One can infer from the principle of goods delivery imposed upon the goods seller under DAP and DPU sales that the seller is discharged of such commitment regardless of the fact that the bill of lading has not been tendered to the maritime carrier. In other words, the bill of lading plays no role in the delivery of goods under both sales. This will lead to a further conclusion that a transfer of risk from the seller to the purchaser under both sales would not be hinged on the fact of surrendering a bill of lading as such passage is determined on the achievement of the delivery obligation, which does not require the surrender of the bill of lading. ${ }^{24}$ Thus, the maritime carrier who has delivered the goods without tendering of the bill of lading under one of these sales shall not be liable vis-à-vis the parties to the contract of sale for such delivery since this delivery would not affect the implications of the this contract, under which the goods delivery takes place at the destination place, even though the maritime carrier has delivered the goods without receiving the bill of lading. Namely, this delivery would be sufficient to release the commitment of delivery and allocation of risk, both of which are imposed upon the seller based on DAP or DPU sale or even under the destination contract governed by the CISG.

The rule of the obligation of delivery imposed under the contract of sale involving the carriage of goods has further been addressed under the English law. According to Article 32(1) of the UK Sale of Goods Act 1979:

"Where, in pursuance of a contract of sale, the seller is authorised or required to send the goods to the buyer, delivery of the goods to a carrier (whether named by the buyer or not) for the purpose of transmission to the buyer is prima facie deemed to be a delivery of the goods to the buyer".

Inference can be made from this Article that the seller would have been discharged of the obligation of delivery, had they delivered the goods to the carrier. In other words, the English law has recognised the default delivery the seller performs to the maritime carrier. However, this rule is related only to sales of shipment, whereby the goods delivery and transferring of risk take place in the port of shipment, such as the commitment of delivery under CIF, FOB and CFR contracts. Hence, one can safely argue that the goods delivery without receiving the bill of lading would not affect the implications of shipment sales because the implications of such contract would have already taken place prior to this delivery, i.e., when the delivery of goods is performed by the seller and the risk transferred to the purchaser at the shipment port.

However, the influence of the delivery of goods without surrendering the bill of lading should also be addressed under

24. The rule of passing of risk has been enshrined in Article A3 of DAP and DPU, which states: 'The seller pears all risks of loss of or damage to the goods until they have been delivered in accordance with A2, with the exception of loss or damage in the circumstances described in B3. 
destination sales, which entail that the goods delivery and transmission of risk shall take place at the place of destination. The rule of delivery of goods under destination contract cannot be found in the English Sale of Goods Act and thus, it could be resorted to the general rules of delivery of goods to derive the main principle of the obligation of delivery of goods. This can be inferred from Section 29(1) of the English Sale of Goods Act:

"Whether it is for the buyer to take possession of the goods or for the seller to send them to the buyer is a question depending in each case on the contract, express or implied, between the parties".

It can be inferred that this section is an application of the principle of Party Autonomy. According to this section, the priority in terms of the rule of delivery shall be given to what has been agreed upon between parties to the sale contract, which might be inferred from the circumstance of the destination sale. ${ }^{25}$ It could be presumed that if the parties to the destination sale stipulated that the delivery of goods has to be performed in exchange for the bill of lading, the delivery obligation would not be discharged unless by surrendering of the bill of lading. One can conclude that the delivery under destination contract governed by the English law will not be affected by non-tendering of the bill of lading.

In order to address the effect of the non-production of bill of lading on the implications of the destination contract under the Qatari law, it is important first to shed light on the rule of delivery of goods, enshrined in Article 104 of the Qatari Commercial Law 2006, which declares that:

"If the sold item must be exported to the purchaser, delivery will not take place unless it reaches them, provided that the agreement does not provide otherwise".

By virtue of this article, the seller's obligation of goods delivery would not be discharged if the goods did not reach the purchaser. Namely, the obligation of goods delivery under destination sale is deemed to be discharged, under the Qatari Law, once the goods arrive at the purchaser place. This may lead to an inference that the Qatari Law stipulates neither the transfer of custody of goods nor the tendering of the bill of lading in order for the obligation of delivery to be discharged under the destination sale.

It can be argued that the principle of delivery under this Article is vague as it has only used the expression 'reaches', which is ambiguous and results in potentiality of various interpretations. In other words, the reader cannot decide whether to consider that the obligation of delivery is discharged once the goods reach the port of destination or the purchaser's place of business or residence. This ambiguity might lead to a construction that this

25. Twigg-Flesner, Canavan and Macquee, Attiah and Adam's Sale of Goods 122, 124 (13 $\left.3^{\text {th }} E d ., 2016\right)$. delivery requires that the custody of goods shall be renounced from the carrier to the purchaser.

To eliminate the contradictive interpretations that could arise when applying this Article, it is necessary to find another legal resort to clarify the delivery obligation intended in this Article. In the absence of such rule under the Qatari Commercial law, it should be resorted to the general rules of the delivery of goods enshrined in the Qatari Civil Law 2004. This has been explained in Article 438 of the Qatari Civil Law:

"Delivery takes place by placing the sold item at the disposal of the purchaser, so that they can possess and benefit from them without hindrance, even if they did not actually take them, provided that the seller has notified them about that. This delivery takes place in a manner consistent with the nature of the item sold".

One can infer from the provisions of this Article as a general rule that the seller's obligation of goods delivery is met once the seller makes the goods available at the disposal of the carrier, regardless of the physical delivery; hence, one can safely conclude that the delivery of goods is duly achieved even if the relevant documents have not been surrendered. Accordingly, one can infer that the maritime carrier's breach of delivering the goods to the purchaser without production of bill of lading would not impact the delivery of goods imposed upon the seller under destination sale.

It can be concluded that the rule of delivery of goods under the CISG 1980 and INCOTERMS Rules 2020 is considered to be achieved when the carrier puts the goods at the disposal of the purchaser regardless of non-surrendering of bill of lading. ${ }^{26}$ This approach is also adopted by the English Sale of Goods Act 1979 and the Qatari Commercial Law, both of which did not require the tendering of bill of lading for discharging of the obligation of goods delivery. The CISG, Incoterms Rules 2020, and the Qatari Civil Law 2004 have all addressed the surrender of the related documents, inter alia the bill of lading, as a separate obligation from the obligation of delivery of goods. ${ }^{27}$ Namely, the seller would be discharged of the obligation of delivery of goods under all of the aforementioned laws though the original bill of lading has not been delivered yet.

26. Al-Daboubi, BAUGHEN, supra note 21 , at 85 .

27. See Article 34 of the CISG and Article A6 of DAP, DPU and DDP of INCOTERMS Rules 2020, which states: 'The seller must provide the buyer, at the seller's cost, with any document required to enable the buyer to take over the goods.' Article 434 of Qatari Civil Law 2004 which provides: 'The seller is obliged to provide the buyer with all necessary information related to the item sold and to surrender the relevant document to them 


\section{IMPLICATION OF DELIVERY OF GOODS WITHOUT SURRENDERING OF BILL OF LADING}

The goods delivery without tendering of the original bill of lading might influence the rights of the other parties, and to clarify the implications of such delivery it is important to distinguish between the effect of this delivery on the parties to the marine carriage contract and contract of international sale of goods.

\subsection{Impact of the Delivery of Goods Without Tendering of Bill of Lading on the Rights of the Parties to the Contract of Marine Carriage}

As explained earlier, the maritime carrier is obliged to deliver the goods in exchange for the original bill of lading, which has to be handed over in the port of destination. ${ }^{28}$ Namely, the maritime carrier under the international conventions, UK COGSA 1992 and QML, will be liable in front of the shipper if they have handed the goods over without receiving the transportation documents from the consignee. According to the provisions of the English and Qatari laws, the bill of lading is deemed to be a document of title, whereby the seller can transfer the ownership of the goods to the buyer. ${ }^{29}$ Therefore, this entails that the maritime carrier, as a party with the physical possession of the goods, shall be obliged to hand the goods over to the lawful holder of the bill of lading. ${ }^{30}$ Such delivery is considered a constructive delivery of the goods, which entitles the lawful holder of the bill of lading to sue the maritime carrier for misdelivery of the goods. ${ }^{31}$ However, the vessel in various scenarios might reach the destination before the arrival of the shipping documents and hence, the maritime carrier would be forced to perform the handing over of goods without surrendering of bill of lading because of such circumstances. Arrival of the goods before receiving the bill of lading by the consignee is attributable to a twofold fact: first, the new technologies in maritime industry aimed at accelerating the navigation operation and shortening the voyage period, and second, the negotiability of the bill of lading due to the sales concluded on the goods while in transit, which would delay

28. Kuwait Petroleum Corporation v I \& D Oil Carriers Ltd (The Houda) [1994] 2 Lloyd's Rep 541.

29. Č. Pejović, Legal Issues Arising from Delivery of Goods without a Bill of Lading: Case Study of Some Asian Jurisdiction, 45 PPP god. 4 (2006); BAUGHEN, supra note 8, at. 8. See section 19 of the Sale of Goods Act 1979 in English law and article 149 of the Qatari Commercial Law. See also Lickbarrow v Mason (1787) 2 TR 64, 69; Official Assignee of Madras v Mercantile Bank of India Ltd [1935] AC 53, PC.

30. Girvin, S., Carriage of Goods by Sea 88, 89 (2 $2^{\text {nd }}$ Ed., 2011); Diadev, I.N., Law and Practice of the Obligations of the Carrier Over the Cargo/The Hague-Visby Rules 11 (2016).

31. Edward Liu and Felix Cheung, A tale of four jurisdictions: delivery of cargo without production of original bill of lading, 25 JIML 433 (2019). the arrival of the bill of lading. ${ }^{32}$ The contradiction between the practices in the maritime industry and the rules of the aforesaid regulations would result in a grey zone as to the responsibility of the maritime carrier for such a delivery. This liability could obviously be borne when the maritime carrier delivers the goods to a party not eligible for such delivery and hence, he would be liable for the breach of contract and misdelivery of goods..$^{33}$ For instance, if the bill of lading has been endorsed by the consignee to a third party, the maritime carrier could be responsible for the delivery without presentation of the bill of lading even though the goods have been delivered to the person named as a consignee in the bill of lading. ${ }^{34}$ The reason of this liability lies in the fact that the goods have been delivered to unrightful holder, while the goods should have been handed over the endorsee to whom the bill of lading has already been endorsed by eligible holder.

In different scenarios, the goods may arrive before receiving the bill of lading by the consignee and the assertion of not delivering the goods without producing a bill of lading would adversely influence the interests of the parties to marine carriage contract. Therefore, some solutions were innovated with a view to overcome such impracticability. The Letter of Guarantee is one of the means that can be used to protect the maritime carrier in case of delivering the goods without tendering of the bill of lading. ${ }^{35}$ The Letter of Guarantee is a document issued by the consignee demanding the shipper to allow the delivery of goods by the marine carrier, as an agent of the shipper, to the consignee regardless of not tendering of the bill of lading. ${ }^{36}$ However, English commercial court has extended the Letter of Guarantee extent by deciding that the delivery under this document is deemed to be duly achieved if such a delivery has been performed to someone who seems to be the representative of the consignee or to the person who is believed to be acting on behalf of the named consignee. ${ }^{37}$ The controversy arising in terms of the obligation of delivering the goods against the bill of lading, and the necessity of delivering the goods without presentation of the bill of lading can also be solved under the English law on the basis of the principle of parties' autonomy, whereby the parties can disregard the requirement of delivering the goods in return for the bill of lading. ${ }^{38}$ The delivery of goods without production

32. Id. at. 434

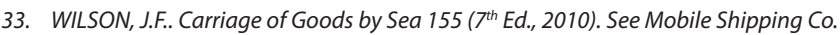
v. Shell Eastern Petroleum Ltd (The Mobile Courage) [1987] Lloyd's rep. 655.

34. Pejović, supra note 29, at 5; See Export SA v Northern River Shipping Ltd [1994] 2 Lloyd's Rep 274; Kuwait Petroleum Corporation v I\& D Oil Carriers Ltd (The Houda) [1994] 2 Lloyd's Rep 541.

35. Pejović, supra note 29 , at 14 .

36. Laemthong International Lines Co Ltd v Abdullah Mohammed Fahem \& Co [2005] EWCA Civ 519

37. Songa Chemicals AS v NaviG8 Chemicals Pool Limited [2018] EWHC 397 (Comm).

38. This can be derived from Section 29(1) of the English Sale of Goods. 
of the bill of lading can also be justified based on the principle of Parties Autonomy under the Qatari law, whereby the maritime carrier can be exonerated from the liability of delivery without tendering of the bill of lading if the contracting parties to the sale contract have already agreed on such a delivery. ${ }^{39}$ In other words, the maritime carrier shall be discharged of the obligation of delivery without presentation of the bill of lading provided that the shipper has waived the requirement of tendering of the bill of lading..$^{40}$ It has further been presumed that the other aspect of discharging such a liability under the English law can be seen in the case that the law or customs in the destination port allow in the strict sense the delivery without surrendering of the bill of lading. ${ }^{41}$ Moreover, the electronic bill of lading has also been innovated for the purpose of solving the matter of delivering the goods that have arrived before the bill of lading reaches the consignee..$^{42}$ This is because such a document can easily and rapidly be received by the consignee, which in turn will enable the consignee to take the goods over in exchange for the E-bill of lading. Unfortunately, the E-bill of lading has not been recognised under the UK COGSA 1992, but Section 1(5) of the UK COGSA 1992 entitled the Secretary of State to expand the scope of this Act to govern 'a telecom system or any other information technology that is used for effecting transactions. ${ }^{43}$ Not only is the UK COGSA 1992 that has not regulated the E-bill of lading, but the QML did not address this bill either. Therefore, one should resort to the Qatari E-Commerce and Transaction Law No. (16), of 2010 , to derive the main rules related to e-contracts, evidentiary effects of e-transactions and e-signature. ${ }^{44}$

It is worth mentioning that according to the English law, the maritime carrier who handed over the goods without receiving the bill of lading shall be entitled to sue the consignee who has received the goods. The recourse in this regard might be based on the contractual liability or tortious liability. ${ }^{45}$ The maritime carrier under the QML is also entitled to the same, but his right has to be based on the general rules to find a legal ground for the delivery in exchange for the Letter of Guarantee or the E-bill of lading, contrary to the English law where the recourse can be had to COGSA 1992 or courts' precedents, as a common law system, in

39. Article 104 of the Qatari Commercial Law 2006.

40. Forsa Multimedia Ltd v C\&C Logistics (HK) Ltd [2011] HKCA 538, HCMP 683/2011; Export SA v Northern River Shipping Ltd [1994] 2 Lloyd's Rep 274; Kuwait Petroleum Corporation v I \& D Oil Carriers Ltd (The Houda) [1994] 2 Lloyd's Rep 599.

41. Cooke et al. supra note 20, at 214. See also, SA Sucre Export v Northern Rovers Shipping Ltd [1994] 2 Lloyd's Rep 275.

42. Al-Marzooqi, supra note 4, at 163, 164.

43. Aikens, R, Lord, R. \& Bools, M., Bill of Lading 145 (2 ${ }^{\text {nd }}$ Ed., 2015); John F Wilson, The Presentation Rule revisited, LMCLQ 166 (1995); Carr, I and Stone, P., International Trade Law 194 (6 $6^{\text {th }}$ Ed., 1995).

44. Al-Marzooqi, supra note 4, at 165.

45. Westwood Shipping Lines Inc $v$ Geo International Inc and Others (24 June 1998) T-359-98 (FCTD). order to legalise the delivery against the E-bill of lading or against the Letter of Guarantee. ${ }^{46}$

\subsection{Impact of Goods Delivery Without Tendering of Bill of Lading on the Rights of the Parties to the Contract of International Sale}

The delivery of goods might play a decisive role under the contract of international sale. This role can clearly be identified in destination sales, in which the delivery of goods as well as allocation of risk happen in the place of destination. ${ }^{47}$ According to the provision of the CISG 1980 and INCOTERMS Rules 2020, the maritime carrier is committed to enable the consignee to take delivery of goods at the destination, which will in turn trigger the passage of risk. ${ }^{48}$ Therefore, one can safely argue that the goods delivery without surrendering of the bill of lading might result in delivering the goods to a party not authorised for such delivery, and this will deprive the legal holder of the bill of lading from taking the delivery, which will adversely impact the obligation of the delivery of goods as well as the transfer of risk under destination sale. Accordingly, the contracting parties to international sales might invoke the delivery without the bill of lading, performed by the maritime carrier, to refute the allegations that the delivery of goods and the transfer of risk have been achieved under destination.

As discussed above, if the parties to the destination sale have stipulated that the goods delivery must be performed in exchange for the bill of lading, the delivery commitment under the contract of sale would not be discharged unless by surrendering of the bill of lading. According to this scenario, the breach of the maritime carrier's obligation of delivering the goods without production of the bill of lading would adversely affect the implications of the sale contract. Namely, the discharge of the seller's obligation of delivery would be hinged on the performance of the maritime carrier of delivering the shipped goods against the bill of lading. Only in this case, the maritime carrier's breach of delivering the goods without surrendering of the bill of lading can influence the commitment of goods delivery imposed upon the seller under destination sale, and this will render the maritime carrier liable against the contracting parties to the sale contract. The transfer of risk might also be affected by delivering the goods without surrendering of the bill of lading under the Qatari Law as the passage of risk is associated to the

46. See section 1(5) of the UK COGSA 1992, The 'Sormovskiy 3068', supra note 6. [1994] 2 Lloyd's Rep. 266; Petroleum Corp v I \& D Oil Carriers (The 'Houda') [1994] 2 Lloyd's Rep. 541; Enichem Anic S.p.A. and Others v Ampelos Shipping Co. Ltd. (The 'Delfini') [1990] 1 Lloyd's Rep. 187. For further explanation see TODD, supra note 1, at 217; Pejović, supra note 29, at 18.

47. The destination sale such as DDP, DAP and DPU of the Incoterms Rules 2020

48. As provided in article A3 of DDP, DAP and DPU of the Incoterms Rules 2020. 
delivery of goods under this law. ${ }^{49}$ The same presumption can also be adopted under the English law, provided that the English Consumer Rights Act 2015 is applicable to such a contract. ${ }^{50}$ One can assume that the maritime carrier's breach of delivering the goods without production of the bill of lading can influence the passage of risk since the Qatari Commercial Law and the English Consumer Rights Act have both linked the passage of risk to the fact of transferring of the physical possession of the goods, provided that the contracting parties to destination sale have stipulated production of the bill of lading in addition to the physical delivery of goods. ${ }^{51}$

\section{CONCLUSION}

From the above-mentioned analysis, a conclusion can be reached that the maritime carrier might be responsible for the delivery of goods without tendering of the bill of lading. This liability might be borne under the contract of marine carriage or under the contract of international sale. The study inferred that the maritime carrier can be liable against the shipper or the consignee for the delivery without surrendering of the bill of lading. This liability is based on the contractual relationship arising from the contract of marine carriage. The author found that the liability arising from the goods delivery without production of the bill of lading could be refuted under the English law, if the maritime carrier has handed the goods over in exchange for the Letter of Guarantee or the E-bill of lading, provided always that the contracting parties did not agree otherwise. The study further concludes that such a delivery can be rebutted under the same law if the contracting parties have previously agreed to disregard surrendering of the bill of lading or if the customs or the rules in the destination port allowed, in the strict sense, the delivery without the bill of lading. However, the English law did not regulate the delivery of goods in exchange for the E-bill of lading. Nonetheless, the UK COGSA 1992 confers on the Secretary of State the right to extend the scope of this law to encompass such a kind of delivery.

The study further found that the Qatari Maritime Law only recognises the case where the contracting parties allow the goods delivery without surrendering of the bill of lading, while the delivery against the E-bill of lading has not been regulated under this law and hence, it is suggested that the recourse has to be had to the Qatari E-Commerce and Transaction Law No.

49. See Article 104 of the Qatari Commercial law.

50. This can be inferred from the fact that the rule of passing of risk has been connected to the time of transferring of property, whereas the risk under consumer right act shall pass at the time the goods have been delivered.

51. Section 29(2) English Consumer Rights Act 2015 provides: 'The goods remain at the trader's risk until they come into the physical possession of (a) the consumer or ( $b$ ) a person identified by the consumer to take possession of the goods.'
(16) of 2010 to legalise this delivery, but the author argues that this Act is not quite fit to regulate the E-bill of lading as this act has been tailored to regulate the e-commercial transactions in general, while the E-bill of lading enjoys different characteristics that cannot be available in the other commercial documents. As opposed to the English law, the QML neither regulated the delivery against the Letter of Guarantee nor the delivery without the bill of lading, which is considered to be legally achieved according to the customs and rules of the destination port.

The study also concludes that the effect of the delivery of goods without production of the bill of lading is not only confined to the implication of the contract of marine carriage, but the contract of sale could also be impacted by this delivery. However, an assumption can be made that the maritime carrier's breach of delivery of goods without surrendering of the bill of lading would not affect the implications of destination sale under each law because the commitment of goods delivery under the sale contract does not entail a surrender of the bill of lading, while the author argues that the implications of the sale contract might be adversely impacted by such delivery if the parties to this contract have stipulated the production of the bill of lading for the purpose of discharging the seller's obligation of delivery. The study also concludes that the transfer of risk in destination sale, governed by either the English or Qatari law, shall not be affected by non-production of the bill of lading unless the parties have already stipulated production of the bill of lading. However, in order for the passage of risk to be affected by this delivery, the English law also prescribed that the destination sale in question shall be considered one that is supposed to be governed by the English Consumer Rights Act 2015. This conclusion has been reached as the seller's obligation of goods delivery shall be satisfied when the seller places the goods at the disposal of the carrier even if the physical delivery has not been achieved.

Since the delivery of goods against the Letter of Guarantee or E-bill of lading is innovated to protect the maritime carrier from the liability of delivering the goods without the bill of lading, one can suggest that both the English and Qatari legislature shall take step forward in order to regulate the delivery against the E-bill of lading as both laws have not expressly addressed the delivery in exchange the E-bill of lading. This might be inspired from the rules of Electronic Transport Records enshrined under the Rotterdam Rules. ${ }^{52}$ The study also recommends that the QML should address the delivery of goods in exchange for the Letter of Guarantee as well as follow in track of the English law of recognising the delivery without tendering of the bill of lading, in particular when such a delivery is consistent with the applicable customs and law in the destination port.

52.1See Articles 9, 18 and 38 of the Rotterdam Rules 2009. 


\section{REFERENCES}

Aikens, L. \& Bools, M., 2016. Bills of Lading. Oxon: Informa Law from Routledge.

Al-Daboubi, Derar., 2019. To What Extent does the Marine Carrier Influence the Passing of Ownership and Risk in International Sales? A Critical Analysis of the International Instruments and Jordanian Law. PhDThesis, Royal Holloway, University of London.

Al-Marzouqi, M., 2017. Carrier Liability Regime under the Qatari Maritime Law: A Comparative Study. J. Mar. L. \& Com. 48, pp. 452-497.

Al-Marzouqi, M., 2018. The Documentary Scope of the Carriage of Goods by Sea Articles under the Qatari Maritime Law and International conventions. 2 International Review of Law. 153-174.

Baughen, S., 2018. Shipping Law. Oxon: Routledge.

Carr, I. and Stone, P., 2013. International Trade Law. Oxon: Routledge.

Chan Leng, S., 1995. Holder of a Bill of Lading. 7 S.A.c.L.J. 355, 366.

Cheung, L,. 2019. Delivery of Cargo without Production of Original Bill of Lading. JIML 25. pp. 432-448.

Coetzee, J., 2013-2014. The Interplay between Incoterms and the CISG. J. L. \& Com. 32, pp. 1-21.

Cooke, Y. et al., 2007. Voyage Charters. Oxon: Informa.

Erauw, Johan. (2011) Passing of Risk. In Kroll, S. et al. UN Convention on Contracts for the International Sale of Goods (CISG): Commentary, pp. 62-82. Germany: $\mathrm{CH}$ Beck/Hart/Nomos.

Girvin, S., 2011. Carriage of Goods by Sea. Oxford: Oxford University Press.
Han, L., 2008. A Study on the Liability of the Carrier and the Actual Carrier for Delivery of Goods without a B/L in China. J. Mar. L. \& Com. 39, pp. 275-287.

Harris, Brian. (2018) Ridley's Law of the Carriage of Goods by Land, Sea and Air. London:Thomson Reuters.

Liu, E. and Cheung, F., 2019. A tale of four jurisdictions: delivery of cargo without production of original bill of lading. JIML 25, pp. 432-442.

Pejović, Č., 2006. Legal Issues Arising from Delivery of Goods Without a Bill of Lading: Case Study of Some Asian Jurisdiction. PPP 45, pp. 1-20.

Piltz, Burghard, 2011. Delivery of the Goods and Handing Over of Documents. In Kroll, S. et al. UN Convention on Contracts for the International Sale of Goods (CISG): Commentary, pp. 393-422. Germany: CH Beck/Hart/Nomos.

Singh, L., 2011. The Law of Carriage of Goods by Sea. Sussex: Bloomsbury Professional.

Todd, P., 2015. Principles of the Carriage of Goods by Sea. Available at: http://dx.doi.org/10.4324/9781315813493.

Twigg-Flesner, Canavan and Hector MacQueen., 2016. Atiyah and Adam Sale of Goods. London: Pearson Education.

William, L., 2008. Misdelivery of Cargo without Production of Original Bill of Lading: Applicability of the Mandatory Legal Regime of the Hague-Visby and the One-Year Time Bar. J Mar L and Com. 39(2), pp. 205-227.

Williams, R., 2009. Letters of Indemnity. J.I.M.L. 15(5), pp. 388-407.

Wilson, J.F., 1995. The Presentation Rule revisited. LMCLQ 152-171.

Wilson, J.F., 2010. Carriage of Goods by Sea. London: Pearson Education. 